Articles

\title{
Planning to maintain the status quo? A comparative study of digital equity plans of four large US cities
}

Caroline Stratton
Assistant Professor, School of Information, Florida State University, USA

cstratton2@,fsu.edu

The term digital equity is at the forefront of municipal government planning to mitigate digital inequality. Digital equity signifies a desired future to be achieved, yet its meaning is not well-established. As such, planning for digital equity offers an opportunity for new discursive construction. This study examines how municipal governments have constructed the concept of digital equity through textual evidence, the digital equity plans of Kansas City, MO, Portland, OR, San Francisco, $C A$, and Seattle, WA. Adopting an approach from critical discourse studies, comparative analysis of the texts demonstrates how digital equity plans conceive of digital equity, characterize current problematic circumstances, and prescribe actions to make change. The plans have strikingly little to say about why digital inequality has emerged; however, they prescribe actions that indicate a more complex understanding of the problem than they articulate. The dynamics of policy diffusion suggest that the work of early adopters will influence other municipalities to create similar plans, so the current moment is ripe for scholars to influence municipal planning for digital equity and participate in its discursive construction in both academic research and policymaking circles. This study offers two recommendations for planners to consider interventions that directly address the barrier of cost of consistent access to devices and Internet service and to incorporate digital equity as a cross-cutting theme in other areas of municipal planning.

\section{Introduction}

The current Covid-19 crisis has rejuvenated interest in public policy to expand access to and use of information and communication technologies (ICTs), yet the federal 
government in the United States has taken little action to address digital inequality in the last half-decade. In the absence of higher level government action, municipal governments have made strides in assessing digital inequality locally and planning to mitigate it. Municipal government plans have diverse origins: some efforts are longstanding and represent decades of coordination between community technology advocates and government, while others are newer and more closely tied to cities' pursuit of private sector investment in next generation telecommunications infrastructure.

At the forefront of municipal planning to mitigate digital inequality is the term digital equity. The National Digital Inclusion Alliance (NDIA), a group promoting policymaking and interventions for digital inclusion, defines digital equity as "a condition in which all individuals and communities have the information technology capacity needed for full participation in our society, democracy and economy" (NDIA, n.d.). The emergence of the term digital equity in municipal planning is interesting for at least two reasons. First, it signifies a desired future to be achieved. It represents a discursive departure from the evolving problem of the digital divide or the process of digital inclusion. Second, its meaning is not well-established. There is a paucity of scholarly or practitioner writing that conceptualizes or otherwise theorizes digital equity, with the exception of a stream of work in the field of education. Definitions offered by advocates such as NDIA are not necessarily conclusive, nor are they unambiguous. As such, planning for digital equity offers an opportunity for new discursive construction.

This study examines how municipal governments have constructed the concept of digital equity through textual evidence, the digital equity plans of Kansas City, MO, Portland, OR, San Francisco, CA, and Seattle, WA. Adopting an approach from critical discourse studies, comparative analysis of the texts demonstrates how digital equity plans conceive of digital equity, characterize current problematic circumstances, and prescribe actions to make change. Despite the opportunities that discursive construction of digital equity offers for newly interpreting the relationship between inequality and technology, the four plans examined herein demonstrate few departures from earlier approaches to addressing digital inequality. The plans have strikingly little to say about why digital inequality has emerged; however, they prescribe actions that indicate a more complex understanding of the problem than they articulate.

Even so, the concept of digital equity may be generative for scholarship about digital inequality. It offers a new site for theoretical and practical intervention. Where scholars may be reluctant to continue engaging with the digital divide as a meaningful concept for discussion and intervention, digital equity offers new possibilities for empirical study, theorizing, and shaping action in the world. The current moment is ripe for scholars to influence municipal planning for digital equity and participate in its discursive construction in both academic research and policymaking circles. To situate the study, the following section reviews the evolution of municipal government planning to address digital inequality and details what the discursive construction of digital equity might offer. 


\section{Literature review}

\section{The origins of municipal government planning to address digital inequality}

The earliest municipal government responses to digital inequality emerged in relation to the community technology movement. This movement has sought to create social benefits and serve community needs through access to and use of computers and digital networks for more than three decades (Beamish, 1999; Morino, 1994; Servon 2002). Servon and Nelson (2002) characterize the movement's original concern as extending access to information to all. Concern about technology's role to exacerbate or mitigate "further isolation and impoverishment" (Servon \& Nelson, 2001, p. 420) of marginalized communities came later. The strategies for change favored by the movement included establishing and operating sites for public access to computers and the Internet and training community members in skills to use these technologies, and to a lesser extent, facilitating community production of digital content. Notably, the movement rarely pursued strategies to provide computers to individuals or extend Internet service into private homes (Beamish, 1999). Scholars have characterized the community technology movement as grassroots, emerging from local needs and seeking local solutions, in the absence of large-scale public or private sector programs to correct disparities (Servon \& Nelson, 2001; Servon \& Pinkett, 2004).

The nature of government's engagement with the community technology movement has varied across municipalities. Some governments established public access sites themselves, while others offered financial and institutional support for other organizations' interventions (Horrigan, 2001; Horrigan \& Wilson, 2002; Servon \& Nelson, 2001). Municipal governments were among the recipients of federal funding for community technology interventions through the National Telecommunication \& Information Administration's Technology Opportunities Program (TOP) (Borgstrom et al., 2005; Horrigan, 2001). Some also provided in-kind support for other organizations to receive TOP funding, which required a financial match for applicants (Horrigan \& Wilson, 2002). Demonstrating a strong role for municipal government, Seattle, WA established a Community Technology Program and hired a dedicated community technology planner to address digital inequality in the mid-1990s (Servon \& Nelson, 2001).

Multiple rationales motivated municipal governments' earliest efforts to address digital inequality. In addition to a social rationale to provide all residents with access to new technologies, governments also saw potential benefits for local economies (Servon \& Nelson, 2001). Cities seeking economic growth through stimulation of the tech industry would need a workforce skilled in the use of computers (Tufekci, 2012). With appropriate training, the urban poor would be able to join the technology workforce and realize new economic opportunity (Sanyal \& Schön, 1999). Scholars in community planning touted these social and economic rationales (Schön, 1999), recommending that local government create wide-ranging benefits for residents through planning.

\section{Support and guidance for municipal planning}

Actors from the private sector would also call on municipal governments to address digital inequality, strongly emphasizing the economic rationale for doing so (Wiig, 2016; Wynne \& Cooper, 2007). Microsoft's Office of Economic Development and Innovation 
issued a 2007 white paper to encourage municipal governments to develop a digital inclusion strategy "as a powerful means to achieve meaningful success for those who, for whatever reason, have been left out" (Wynne \& Cooper, 2007, p. 2) and to gain economic competitive advantage. The white paper offers recommendations for municipal government strategy, including identification of the actors that should be included in developing and implementing the strategy, technology and financial sector leaders among them. Private sector guidance has proved influential. Wiig (2016) demonstrated how IBM effectively transferred its policy recommendations for digital inclusion to the municipal government of Philadelphia, PA. IBM representatives promoted Philadelphia's emergence as a so-called smart city in conjunction with a program to train 500,000 marginalized residents in the use of new technologies. Attracting next-generation telecommunications infrastructure has also motivated municipal planning. For example, Charlotte, NC developed a plan for digital inclusion coincident with Google Fiber's announcement that it would build a fiber optic network in the city (Schools, Health and Libraries Broadband Coalition, 2016).

In addition, civil society and public sector organizations have provided guidance for planning. Entities such as the Federal Reserve Bank of Kansas City, the U.S. Institute of Museum and Library Services (IMLS), and NDIA have published similar and often overlapping frameworks for how government should plan, implement, and evaluate processes of digital inclusion (Federal Reserve Bank of Kansas City, 2019; IMLS, University of Washington, International City/County Management Association, 2012; NDIA, 2019). To achieve digital inclusion, municipal government and other collaborators need to gather stakeholders, develop a plan attuned to local circumstances, and implement the plan (IMLS, University of Washington, International City/County Management Association, 2012). Plans should prioritize the "three-legged stool" (Federal Reserve Bank of Kansas City, 2019, p. 4) of access to broadband Internet service, access to computers, and digital skills. NDIA adds technical support and "empowering content and applications" to the three priority items in its guidance (2019). The framework from IMLS proposes a set of principles for plans to expand access, inform and train the public to encourage adoption of computers and Internet, and support specific applications of technology for economic development, education, healthcare, public safety, and civic and social life (IMLS, University of Washington, International City/County Management Association, 2012).

\section{Limitations of prevailing guidance}

The prevailing guidance about how municipal planning can address digital inequality obscures two key points. First, the prescriptions that advocates currently recommend have not changed substantially from the earliest strategies employed by the community technology movement, but the contours of digital inequality have changed. The diffusion of computers and Internet service has not erased differences in users' skills and outcomes of technology use (DiMaggio \& Hargittai, 2001) and the barrier of affordability has persisted (Strover, 2014). Research about the specific hardware, software, and Internet connections that users have access to (Napoli \& Obar, 2014; van Deursen \& van Dijk, 2019) and the consistency of users' access, both public and private (Gonzales, 2016), suggests that strategies to reduce digital inequality must consider access with far greater nuance than a binary have/have not conception. 
Second, trenchant critiques have indicated the limitations and even the risks of recommended strategies. The notion that all users can and will engage in desirable, capital-enhancing uses of technology if provided access and equipped with adequate skills runs counter to research about digital inequality (van Deursen et al., 2015; Zillien \& Hargittai, 2009). Kvasny's (2006) study of a community technology initiative illustrated how prescribing expanded public access to ICTs and training may reproduce digital and other forms of inequality. She analyzed an initiative operating with the rationale that training underserved communities to use ICTs would improve their economic opportunities. She found that a mismatch in the skills that participants acquired and the structure of the labor market made their advancement unlikely. Uncredentialed (or informally credentialed) training from a community technology center did little to facilitate participants' entry into better paying jobs requiring ICT skills. Her study suggested that governments would need to coordinate with employers to effectively train and place participants for economic advancement but that advancement was unlikely to materialize without also attending to inequitable health, housing, education, and public safety systems that shaped participants' lives and livelihoods.

The work of Eubanks $(2007,2012)$ has highlighted that distributing material and informational resources, like access and training, to the deprived is unlikely to bring about desired outcomes of individual and community thriving. She characterized a distributive paradigm that "fails to bring social structure and institutional contexts . . . under evaluation" (2007, p. 4). Without examining the structure of the information economy and its relation to inequality, distributive interventions cannot transform the problem of digital inequality, nor can they create nonmaterial social goods such as empowerment and opportunity for marginalized people that are established relationally among social groups and institutions. The companies that design and provide technological products and services and the governments that regulate them figure into digital inequality (DiMaggio \& Hargittai, 2001; DiMaggio et al., 2004), but prevailing guidance largely ignores their roles in shaping the problem.

Recommended strategies may also present risks for people they aim to help. Gangadharan $(2012,2017)$ has pointed to the potential harms that participants in digital inclusion trainings face related to privacy and surveillance. Marginalized participants may be exposed to new and heightened forms of exploitation as they use the Internet. Gangadharan (2017) observed that participants received little support within digital inclusion trainings to evaluate and address privacy risks and that federal policy has done little to reduce the vulnerability that new Internet users may experience.

\section{The discursive construction of digital equity through planning}

Recently, digital equity has surfaced as a watchword for government efforts to address digital inequality. Municipal governments have initiated plans for digital equity (Rhinesmith, 2016) and the federal government's use of the term also signals its growing political cachet. Two bills introduced in the $116^{\text {th }}$ United States Congress foregrounded digital equity and defined it as "the condition in which individuals and communities have the information technology capacity that is needed for full participation in the society and economy of the United States" (Digital Equity Act of 2019, 2019; Accessible, Affordable Internet for All Act, 2020). NDIA employs a similar definition for the term, adding participation in democracy to the final clause (NDIA, n.d.). Such a definition is indeterminate. It rests on two ambiguous components, information technology capacity 
and full participation in society, the economy, and democracy. What digital equity means, conceptually and practically, and how to achieve it is not well-established.

Additionally, scholarly inquiry has done little to conceptualize or otherwise theorize digital equity, with the exception of a stream of work in the field of education. Scholars interested in government responses to digital inequality have employed the term digital equity (Eubanks, 2007; Stratton et al., 2020; Strover, 2019), but their work has not pursued conceptualization. Farther afield, education scholars have done more to theorize the term (Gorski, 2003, 2009; Resta, 2020; Resta \& Lafierre, 2008), though their work is not a likely touchstone for municipal planning. It does, however, speak to its potential as a discursive construction. Gorski (2003) made a case for a digital equity movement with a social justice orientation that seeks to dismantle institutionalized privileges of racism, sexism, classism, English-language bias, and ableism that feature in digital inequality.

Through planning, municipal governments and other stakeholders are actively constructing the concept of digital equity and notions about how to achieve it. Planning is a way of knowing, a practice that allows leaders to determine what to do about a problematic situation (Bryson et al., 2009; Bryson, 2018). The process of planning produces official texts for governments to follow and for the public record (Turner, 2001). The implementation and evaluation of plans as written certainly cannot be taken for granted (Poister \& Streib, 2005), but even those plans not acted on as intended contribute to discourse and have material consequences through the language they use to describe problems and proposed solutions (Laws, 1994). Planning for digital equity offers an opportunity to understand and address digital inequality in new ways. It is an ideal condition to be envisioned and achieved. The conditions producing inequity may be described more expansively than individual deficits, just as the processes to facilitate digital equity may go beyond the distributive paradigm. Noting this opportunity, this study poses two research questions to interrogate the discursive construction of digital equity in municipal planning.

\section{RQ1: How do municipal plans conceive of digital equity?}

RQ2: To what extent does planning for digital equity permit new understandings of digital inequality and new strategies to address it?

\section{Methods}

\section{Selection of plans}

This study examines the texts of four municipal digital equity plans. The plans of Kansas City, MO, Portland, OR, San Francisco, CA, and Seattle, WA were selected for study because they describe specific courses of action to bring about digital equity and use the term in their titles (e.g., Digital Equity Action Plan) and throughout their texts. As this study attends to the construction of a discourse about digital equity, municipal plans organized around and titled with other terms, such as digital inclusion, were excluded from selection. The publicly available plan documents were located on the websites of municipalities. The four selected plans were published within the last five years (Portland and Seattle in 2016, Kansas City in 2017, and San Francisco in 2019) and represent the stated intentions of municipal government to address digital inequality. Annex 1 provides additional detail about the plan documents. 
Characteristics of the four municipalities that convey the context for planning are summarized in Table 1. The four municipalities vary in population size and the share of residents who may experience digital inequality (the presence of a household broadband Internet subscription offers a coarse proxy measure for the phenomenon). They have in common strong technology sectors that saw the highest rates of change in their national shares of tech jobs between 2015 and 2017, during a period in which these jobs became more concentrated in specific geographical areas (Muro \& Whiton, 2018). Across municipalities, the financial resources, organization, and planning history available within government to address digital inequality differ substantially. The governments of Portland and Seattle feature dedicated organizational units and funding for community technology; San Francisco and Seattle have relatively longer histories of planning to address digital inequality.

Table 1: Characteristics of municipalities

\begin{tabular}{|c|c|c|c|c|}
\hline & Kansas City & Portland & San Francisco & Seattle \\
\hline $\begin{array}{l}\text { Population } \\
\text { (2019 estimate) }\end{array}$ & 495,327 & 654,741 & 881,549 & 753,675 \\
\hline $\begin{array}{l}\text { Households } \\
\text { with a } \\
\text { broadband } \\
\text { Internet } \\
\text { subscription } \\
\text { (2015-2019 } \\
\text { multi-year } \\
\text { estimate) }\end{array}$ & $81.3 \%$ & $88.3 \%$ & $87.6 \%$ & $90.4 \%$ \\
\hline $\begin{array}{l}\text { Metropolitan } \\
\text { area's national } \\
\text { share of digital } \\
\text { services jobs } \\
\text { (2017) (Muro \& } \\
\text { Whiton, 2018) }\end{array}$ & $1.1 \%$ & $0.9 \%$ & $5.7 \%$ & $4.3 \%$ \\
\hline $\begin{array}{l}\text { Annual } \\
\text { municipal } \\
\text { government } \\
\text { operating } \\
\text { budget (FY 20- } \\
\text { 21) }\end{array}$ & \$1.77 B & $\$ 5.60 \mathrm{~B}$ & \$13.7 B & $\$ 6.64 \mathrm{~B}$ \\
\hline $\begin{array}{l}\text { Municipal } \\
\text { government unit } \\
\text { responsible for } \\
\text { digital equity, } \\
\text { (FY 20-21 } \\
\text { approved } \\
\text { budget } \\
\text { allocation) }\end{array}$ & $\begin{array}{l}\text { City Manager's } \\
\text { Office (no } \\
\text { direct budget } \\
\text { allocation } \\
\text { available) }\end{array}$ & $\begin{array}{l}\text { Office for } \\
\text { Community } \\
\text { Technology } \\
\text { (\$1.23 M for } \\
\text { Broadband \& } \\
\text { Digital Inclusion) }\end{array}$ & $\begin{array}{l}\text { Mayor's Office } \\
\text { of Housing and } \\
\text { Community } \\
\text { Development, } \\
\text { Committee on } \\
\text { Information } \\
\text { Technology, City } \\
\text { Administrator's } \\
\text { Office (no direct } \\
\text { budget allocation } \\
\text { available) }\end{array}$ & $\begin{array}{l}\text { Community } \\
\text { Technology } \\
\text { Program within } \\
\text { Department of } \\
\text { Information } \\
\text { Technology } \\
\text { (\$1.9 M for } \\
\text { Community } \\
\text { Technology \& } \\
\text { Broadband) }\end{array}$ \\
\hline $\begin{array}{l}\text { Related } \\
\text { government } \\
\text { planning history }\end{array}$ & $\begin{array}{l}\text { Plan adopted in } \\
2017 \text {, activities } \\
\text { began around }\end{array}$ & $\begin{array}{l}\text { Plan adopted in } \\
\text { 2016, digital } \\
\text { equity focus first }\end{array}$ & $\begin{array}{l}\text { Plan adopted in } \\
\text { 2019, earlier } \\
\text { Digital Inclusion }\end{array}$ & $\begin{array}{l}\text { Plan adopted in } \\
2016 \text {, study } \\
\text { phase }\end{array}$ \\
\hline
\end{tabular}




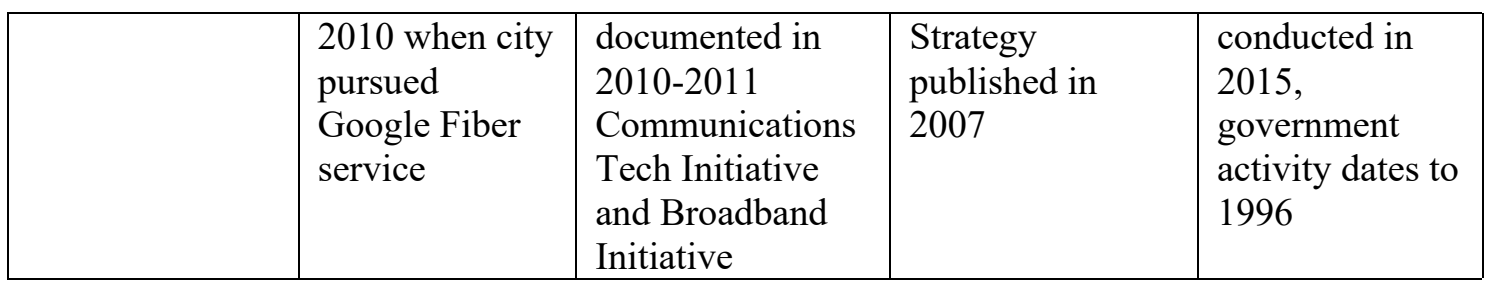

Sources: American Community Survey, municipal budget websites

\section{Analytical approach and process}

This study adopts an approach from critical discourse studies that takes discourse to be socially shaped and socially constitutive (Fairclough \& Wodak, 1997; Wodak \& Meyer, 2015). Discourse is constructed and circulated by social actors in relation to each other, structures, and institutions; the discourse they construct and circulate in turn shapes relationships, structures, and institutions. A critical discourse studies approach considers discourse to be "mostly intentional, controlled, purposeful human activity" (van Dijk, 1997, p. 8). The talk and text comprising discourse are produced in social situations, so their interpretation should consider contextual features, such as who participated, and how production occurred. A critical discourse studies approach also entails a commitment to understanding and addressing inequality (van Dijk, 1993). Discursive acts may produce and reify relations of dominance and inequality, just as they may transform such relations. The texts under study here are ostensibly blueprints for transforming relations of inequality. Accordingly, this analysis examines how the texts construe inequality and propose its mitigation.

Municipal digital equity plans are socially consequential in three respects. First, plans inscribe local interpretations of the concept of digital equity for further use. Inscribed interpretations contribute to a discourse about digital equity, proposing how others ought to interpret the concept or providing a point of origin for alternative interpretations. Second, plans prescribe courses of action to create social change. They present argumentation to support their prescriptions, to the exclusion of other possible prescriptions. The justification for a particular prescription rests on description of the desired goal state and the current problematic circumstances, as well as how the prescription will move from the current problematic circumstances towards the goal state (Fairclough \& Fairclough, 2012; Kennedy, 2016). Argumentation calls for action in the social world, such as behavior change, resource allocation, or policy creation. Third, plans allow for policy diffusion, the spread of common interpretations and prescriptions across governments through mechanisms such as imitation, learning, and competition (Shipan \& Volden, 2008). Plans may be replicated and modified by other actors in other communities. In sum, municipal digital equity plans are partially constitutive of a discourse about digital equity and they shape local action in the social world, with potential for broader effect beyond their original contexts.

The analytical process entailed iterative close reading of the plans to consider their contributions to a discourse about digital equity, their argumentation, and the contexts of their production. The comparative analysis prioritized four items: (1) plans' proposed conceptions of digital equity - the desired goal state, (2) plans' descriptions of the inequitable status quo - the current problematic circumstances, (3) plans' prescribed courses of action for pursuing digital equity - the claims about how to make change, and (4) evidence about their authorship. The first item corresponds closely to RQ1, while the second and third items speak to RQ2. The fourth item contributes to a contextually- 
situated interpretation of the findings. The following section lays out the findings about these four items, comparing similarities and differences across plans.

\section{Findings}

\section{Conceiving of digital equity}

Across the four municipal plans, a proposed conception of digital equity appears most directly in two textual elements, statements defining digital equity and statements of a vision for digital equity. Two plans (Portland and Seattle) include both elements. The other two plans offer one element, definition (Kansas City) or vision (San Francisco), as evidence of discursive construction. The difference between a definition of digital equity and a vision of digital equity in these texts lies in scope and specificity. A definition of digital equity is an ideal condition to be achieved. A vision of digital equity specifies how the condition should be achieved for a particular place and people.

Portland's definition of digital equity comprises the ideal condition of uniform access to and availability of resources: Internet, hardware, software, content, services, and skills training. Its vision of digital equity finds this condition achieved locally so that all residents "will have barrier-free access to high-speed broadband Internet at home and school, an affordable computing device and the training to use them effectively" (City of Portland, 2016, p. 3). Seattle's plan takes a similar tack, defining digital equity as information technology capacity needed for particular activities: civic and cultural participation, work, education, and access to services. The vision depicts the condition achieved locally and particularly among disadvantaged residents, seeking that "technology's opportunities equitably empower all residents and communities especially those who are historically underserved or underrepresented" (City of Seattle, 2016, p. 8).

Further reflecting the distinction between defining and envisioning digital equity, Kansas City's definition of digital equity is an ideal condition, a restatement of the NDIA definition appended with the mention of "digital access to essential services, civic and cultural participation, lifelong learning, employment, entrepreneurship, and economic mobility" (City of Kansas City, 2017, p. 5). It lacks explicit statement of how the ideal condition would be achieved at the local level. In contrast, San Francisco's vision of digital equity foregrounds achievement of "full and equitable access to digital technology and its benefits so all San Francisco residents and communities can thrive" (City of San Francisco, 2019, p. 5).

The preceding definitions and visions of digital equity convey that equity is about the distribution of resources and capabilities to use those resources to particular groups. Seattle's vision of digital equity distinguishes equity from equality, stipulating that equity is about "fairness" for members of historically underrepresented communities, so that they may "achieve their personal goals and contribute to society" (City of Seattle, 2016, p. 6). Equality, alternatively, would entail the uniform distribution of identical resources and services to everyone. San Francisco's plan also attends to this difference to justify its approach. Those "in need of the most support to be fully connected" (City of San Francisco, 2019, p. 10) will be prioritized. 


\section{Describing the inequitable status quo}

Pursuing the desired goal state of digital equity implies that it has not been achieved thus far. The status quo is inequitable in some way, thereby motivating and legitimating the plan to effect change. The four plans describe current problematic circumstances: they name a problem, identify who experiences it, and present evidence about it. All four plans use the term barriers to signify the conditions that individuals experiencing the problem cannot easily overcome without intervention. Three plans include evidence about other features of the problem that are not individual barriers. Table 2 summarizes the plans' descriptions of the current problematic circumstances, organized to facilitate comparison across plans and generally replicate the language (including order of appearance) that they employ.

Table 2: Plans' descriptions of current problematic circumstances

\begin{tabular}{|l|l|l|l|l|}
\hline & Kansas City & Portland & San Francisco & Seattle \\
\hline $\begin{array}{l}\text { Name of the } \\
\text { problem }\end{array}$ & Digital divide & $\begin{array}{l}\text { Digital } \\
\text { exclusion, } \\
\text { digital divide }\end{array}$ & Digital divide & $\begin{array}{l}\text { Digital gap, } \\
\text { digital equity gap, } \\
\text { digital divide }\end{array}$ \\
\hline $\begin{array}{l}\text { Who } \\
\text { experiences it? }\end{array}$ & $\begin{array}{l}\text { Lower income } \\
\text { residents, } \\
\text { residents living in } \\
\text { particular } \\
\text { neighborhoods in } \\
\text { the city }\end{array}$ & $\begin{array}{l}\text { Lower income } \\
\text { residents, older } \\
\text { adults, } \\
\text { communities of } \\
\text { color, people } \\
\text { with disabilities, } \\
\text { and residents } \\
\text { with limited }\end{array}$ & $\begin{array}{l}\text { Lower income } \\
\text { residents, } \\
\text { residents with } \\
\text { limited English } \\
\text { proficiency, } \\
\text { seniors, residents } \\
\text { with disabilities } \\
\text { profish }\end{array}$ & $\begin{array}{l}\text { Immigrants and } \\
\text { refugees, lower } \\
\text { income residents, } \\
\text { historically } \\
\text { underserved and } \\
\text { underrepresented } \\
\text { communities }\end{array}$ \\
\hline $\begin{array}{l}\text { Barriers of } \\
\text { individuals } \\
\text { experiencing } \\
\text { the problem }\end{array}$ & $\begin{array}{l}\text { Cost, lack of } \\
\text { devices, lack of } \\
\text { awareness of } \\
\text { public access } \\
\text { points, lack of } \\
\text { transportation to } \\
\text { spatially } \\
\text { dispersed public } \\
\text { access points }\end{array}$ & $\begin{array}{l}\text { Cost, lack of } \\
\text { devices and } \\
\text { training, scarcity } \\
\text { of culturally- } \\
\text { specific training }\end{array}$ & $\begin{array}{l}\text { Affordability of } \\
\text { devices and } \\
\text { connectivity: } \\
\text { upfront and } \\
\text { maintenance } \\
\text { costs; barriers to } \\
\text { training: } \\
\text { unreliable } \\
\text { access, challenge } \\
\text { of learning, } \\
\text { limited English } \\
\text { proficiency, } \\
\text { competing } \\
\text { demands on time }\end{array}$ & $\begin{array}{l}\text { Lack of devices, } \\
\text { limitations of old } \\
\text { devices, lack of } \\
\text { transportation to } \\
\text { public access } \\
\text { points, lack of } \\
\text { affordable } \\
\text { Internet service } \\
\text { (at home and } \\
\text { mobile), challenge } \\
\text { of learning, } \\
\text { challenge of } \\
\text { finding } \\
\text { appropriate } \\
\text { training, youth } \\
\text { have false sense } \\
\text { of confidence in } \\
\text { their digital skills }\end{array}$ \\
\hline $\begin{array}{l}\text { Other features } \\
\text { of the problem }\end{array}$ & $\begin{array}{l}\text { Low median } \\
\text { income, high } \\
\text { levels of poverty } \\
\text { and } \\
\text { unemployment, } \\
\text { city has large }\end{array}$ & $\begin{array}{l}\text { Organizational } \\
\text { barriers: lack of } \\
\text { adequate devices } \\
\text { for community } \\
\text { programs, lack of } \\
\text { funding and } \\
\text { volunteer support }\end{array}$ \\
\hline
\end{tabular}




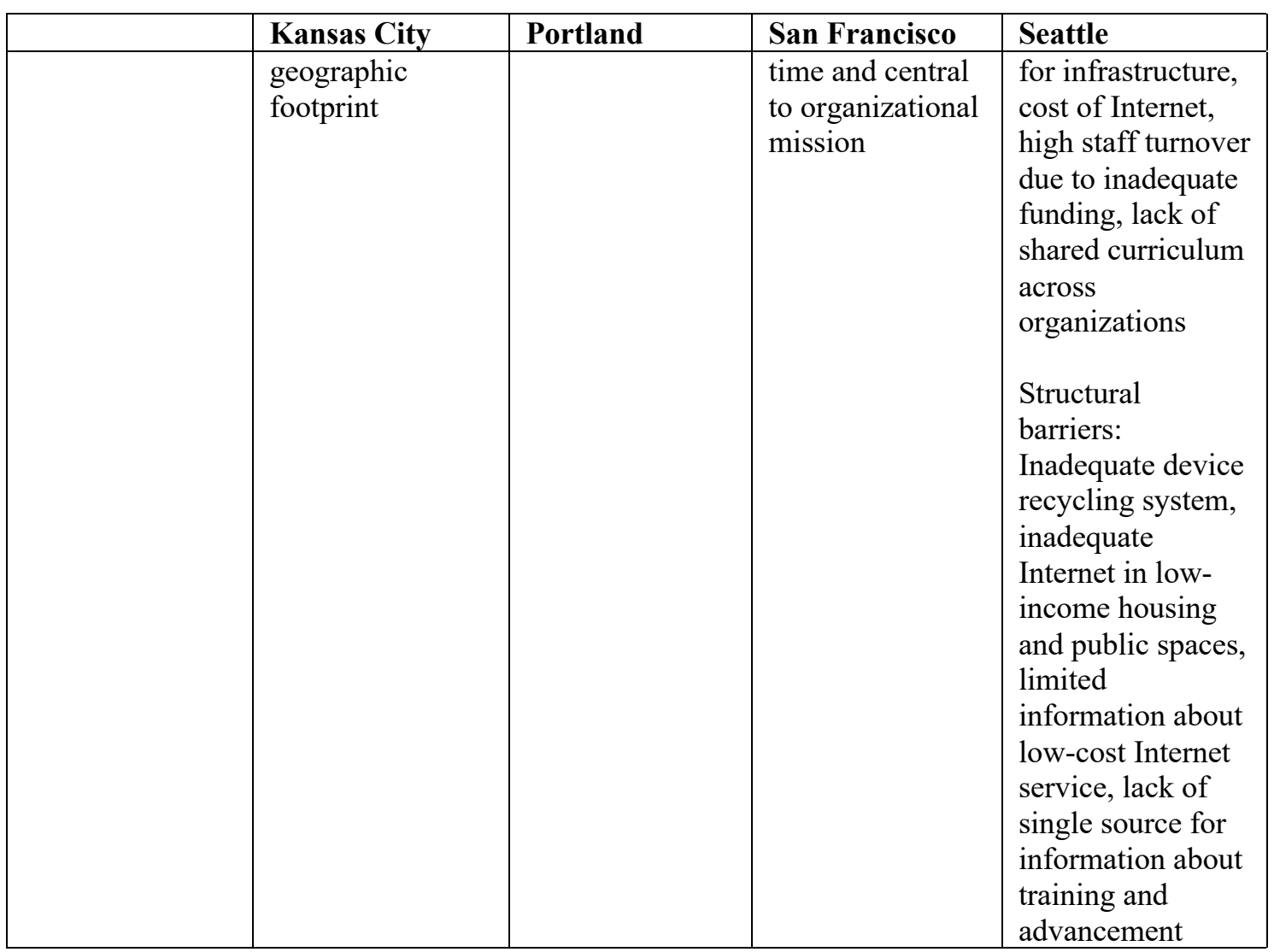

All four plans use the term digital divide to name the problem, though the plans of Portland and Seattle use additional terms throughout their texts when referring to the problem. Portland's plan points to the cost of digital exclusion, which endangers "full participation in nearly every aspect of American society - from economic success and educational achievement, to positive health outcomes and civic engagement" (City of Portland, 2016, p. 4). Seattle's plan responds to a problem named variously as the digital gap, the digital equity gap, and the digital divide throughout its text. Those residents experiencing the problem cannot "participate fully in our high-tech economy and community" (City of Seattle, 2016, p. 1).

The two plans that refer only to the digital divide as the name of the problem (Kansas City and San Francisco) point to differences between residents who have the resources of access to devices and Internet and the skills to use them and those who do not. San Francisco's description of the digital divide attends to two components: disparities in home Internet and computing device access and disparities in digital literacy skills among residents. Kansas City's plan echoes the same disparities and adds that the digital divide also emerges in "misunderstandings of privacy and the relevance of the Internet" (City of Kansas City, 2017, p. 5). In other words, the digitally divided may also be mistaken about how and why they should use computing devices and the Internet.

Identification of who experiences the problem is similar across plans. Lower income residents figure in all four documents. People with limited English proficiency are mentioned in the plans of Portland and San Francisco; this demographic may overlap with the immigrants and refugees invoked in Seattle's plan. Other members of marginalized communities, such as people with disabilities and people of color, as well as those belonging to the catchall demographic of "historically underserved and underrepresented 
groups" (City of Seattle, 2016, p. 1) find themselves afflicted by the problem to a greater extent than residents who are not members of these communities.

Tautologically, all four plans note that a lack of access to devices and Internet, accompanied by a lack of training to use them, are individual barriers to overcoming the problem. The unaffordable cost of devices and Internet service figures explicitly in three plans (Portland, Kansas City, San Francisco). Afflicted individuals may also not know about options for public access in their communities (Kansas City) or have adequate transportation to reach such places (Kansas City, Seattle). Youth may not realize their technology skills are inadequate because of a false sense of confidence (Seattle), while individuals who do manage to access training encounter challenges to learning, including the difficulty of mastering new skills (San Francisco, Seattle).

Evidence about other features of the problem is less consistent across plans than evidence about individuals. Kansas City's plan points to indicators of the local economy that do not favor individuals' chances to overcome problematic circumstances. It also speaks to the problem's geospatial nature. The city's large geographical area, combined with residents' lack of personal transportation to reach dispersed public access points limits access to and use of technologies in those places. San Francisco's plan notes financial and organizational challenges of community-based organizations that attempt to pursue digital equity. Seattle's plan identifies organizational and structural barriers to achieving digital equity. Organizational barriers are similar to those noted in San Francisco's plan, related to the internal operations of community-based organizations. So-named structural barriers refer to the external-facing challenges of those organizations, where a lack of infrastructure, coordination, and central sources of information hampers success.

\section{Prescribing a course of action towards digital equity}

A course of action towards digital equity should proceed from the current problematic circumstances towards the desired goal state. The four plans prescribe a variety of actions to this end, outlined and categorized in Annex 2. Three categories of actions, those to expand access to Internet and computing devices and provide training, respond most directly to plans' conceptions of digital equity and their characterizations of the current problematic circumstances.

Actions to expand access to Internet include those that expand availability of free Wi-Fi access (in public places and through loaning out mobile hotspots) and wired broadband access (in affordable housing and through commercial ISPs). The plans of Portland and San Francisco make mention of incentives to encourage ISPs to expand low-cost options for residential service. San Francisco's plan specifically mentions "greater use of City assets like fiber optic facilities" and partnering with companies that utilize "emerging wireless technologies" (p. 23) so that ISPs will extend infrastructure and service at a lower cost to residents unable to afford service at present.

Three plans prescribe an action to expand access to computing devices through a recycling system. Devices past their useful lives within government and other organizations can be provided to residents in need through a recycling system. Seattle's plan includes a unique action to pilot a subsidy for device purchase, a "scholarship, voucher, or financing option to obtain laptops or desktops for low-income residents who want to buy devices, or for those who complete a foundational skills training program 
through a qualified partner (City of Seattle, 2017, p. 19). This is the only action prescribed across the plans to directly increase personal ownership of new computing devices.

Actions to offer new and expanded training to residents are few, likely because community-based organizations take on these efforts to a greater extent than municipal governments do. Thus, Portland's prescribed action to develop culturally-relevant training curricula may rely on other organizations to implement the curricula and offer the training to the public. Seattle's plan includes training for two specific groups, families with children in Title I schools (institutions with at least $40 \%$ of students from lowincome households) and workers in small businesses owned by minorities and women.

Actions to compile information about and promote community use of options for access and training, such as creating inventories of Internet service, training, and tech support options, imply an aspect of the problem mostly unarticulated in plans - a lack of awareness about existing resources. Kansas City's plan notes the lack of awareness of public access points in its characterization of the problem of the digital divide, but the other plans are silent about the underutilization of resources related to a lack of public awareness. Alternatively, actions to compile information for use by government and community-based organizations, such as creating inventories of government programs related to digital equity and gathering data about connectivity in affordable housing, suggest another type of information gap: organizational understanding of the status quo is incomplete and/or it requires ongoing data gathering to capture change.

Two plans, those of Portland and Seattle, include actions to develop the pipeline of residents into high-tech jobs. Actions in Portland's plan point to support of programs (presumably already existing in the community) that prepare and place underrepresented residents in jobs in the technology economy and that support learning in K-12 education. Alternatively, Seattle's plan calls for STEM and coding education for out-of-school youth and adults. These actions are notable for their divergence from other categories of action and for their loose linkage to the problems presented in the plans. Although the plans of Portland and Seattle reference how the current problematic circumstances may impede economic participation, they do little otherwise to motivate this category of action.

Capacity-building of community-based organizations includes actions to improve communication, funding availability, and coordination across organizations that pursue digital equity in their programs. Two plans (San Francisco and Seattle) include organizational challenges in characterizing the problem. Nonetheless, all four plans prescribe actions, indicating that such challenges are pervasive. Each plan prescribes at least one action to fund community-based organizations' efforts. Kansas City's plan identifies a specific public source of funding through fees for builders of 5G telecommunications infrastructure.

Actions prescribing new formal policies or changes to formal policies are limited. Seattle's plan identifies the potential to revise building codes for multi-dwelling units to support broadband Internet infrastructure. The prescription of additional government planning dominates Kansas City's listed recommendations for action, deeming the City Manager responsible for developing six new thematic roadmaps related to digital equity.

A final category of actions includes those that do not fit easily within other groupings. They include to-be-determined actions, such as pilot projects and community challenges. Seattle's plan includes two additional activities that are supportive of device use (tech 
support, charging stations) but do not seek to directly effect change in access to computing devices.

\section{Authorship and participation}

The texts of the plans offer official descriptions of who participated in plan construction and in what ways. Three of four plans are authored by municipal government, as described in visual and textual elements. The plans of Kansas City, San Francisco, and Seattle are inscribed with the seals of those municipalities and each begins with a letter from the mayor about the plan. The letters offer official legitimation of the text of the plan and express executive endorsement for the courses of action prescribed within. In contrast, Portland's plan is authored by the Digital Inclusion Network, a group of organizations within and outside of the public sector. It bears the seals and logos of the City of Portland, Multnomah County, the City of Portland's Office of Community Technology, and the Multnomah County Library. These entities are also credited with funding and leading the collaborative development of the plan.

Descriptions of the participation of organizations appear in varying levels of detail. Portland's plan identifies 48 organizations participating in workshops to develop the plan, convened by an outside consulting firm. The list of participants includes private sector telecoms (Comcast and Google Fiber), educational institutions, government offices, and non-profits. Seattle's planning process included interviews with 17 representatives of community-based organizations (not identified in the plan) about their programs, practices, and barriers. San Francisco's plan reports that authors met with leaders of city agencies, community-based organizations, tech companies, and telecoms to gather perspectives. The plan acknowledges engagement with 53 community-based organizations, 13 private companies (Comcast, AT\&T, Google, Microsoft, and Twitter among them), 15 local government entities, and 12 non-local government entities. Kansas City's plan simply notes that it includes input from a local coalition for digital equity.

Consultation with the public, including individuals afflicted by the problem, is also documented in plan texts. Portland utilized an outside consulting firm to convene five focus groups for Vietnamese speakers, Chinese speakers, Spanish speakers, people who are deaf and/or hard of hearing, and African-Americans. Planners in Seattle held four community discussions that drew 39 individuals from unnamed "community-based and business organizations" (City of Seattle, 2017, p. 10). San Francisco's plan cites public engagement with more than 400 residents belonging to demographic groups of interest through focus groups and individual interviews. Notably, the authors solicited feedback on a draft plan from residents. Kansas City's plan reports five community engagement meetings at community centers and libraries, as well as public comment solicited and submitted online.

\section{Discussion}

\section{Discursive construction of digital equity}

The discursive construction of digital equity emerges in multiple textual elements of the plans. In general, the plans propose that when the goal state of digital equity is achieved, all residents will have access to computers and Internet (public and/or private) and the skills to use them. This goal state, ideally, leads to particular beneficial uses of ICTs (e.g., 
for economic activity and civic participation), that in turn lead to positive outcomes of individual and community thriving. Digital equity fits neatly within the distributive paradigm (Eubanks, 2017, 2012), as plans allege that the problem is primarily one of individual deficit, so it may be corrected through material and informational resource distribution. Additionally, the plans claim, relational social goods such as empowerment should follow from resource distribution. The vision of digital equity in San Francisco's plan exemplifies the claim: Digital equity entails full access to technology and its benefits, but the process by which benefits develop and accrue to users is left unexplored.

The plans of San Francisco and Seattle employ the caveat that equity is about prioritizing groups with high need, such as those who have been historically underserved and underrepresented (presumably by and within municipal government itself). Prescribed actions also indicate that equity signifies that the resources to be distributed to the deprived will not be identical to those that privileged residents possess. High need groups are to make do with recycled computing devices, existing low-cost Internet programs offered by commercial ISPs, public Wi-Fi access, and the safety net of public access points. In some plans, the sufficiency of secondhand devices is implied alongside stated concerns about access to tech support and the limitations of older devices. Thus, equity signifies both who will be served by plans and the quality of resources to be distributed.

The conception of digital equity conveyed in the plans does not call for substantive reorganization of the social world, nor does it call for change to social, political, or economic structures. The critical discourse studies approach sensitizes this analysis to relations of dominance that shape inequality (van Dijk, 1993) and the analysis finds such relations to be largely invisible in digital equity plans. If, as plans describe, affordability of computing devices and Internet service is the most significant barrier to digital equity, there are few prescribed actions that reduce the cost of those items for afflicted individuals and fewer that would change the way the items are priced. Alternatively, strategies to increase the financial resources that deprived individuals have available for computing devices and Internet service are nonexistent. Other intertwined systems within the purview of municipal government that shape economic opportunity, including healthcare, housing, education, and public safety (Kvasny, 2006), play little role in the conception of digital equity, though they surface to varying degrees in prescriptions for change.

While the plans are far from radical in their proposals to transform inequality, they do adhere to the guidance for both process and content offered by the array of civil society and public sector institutions introduced earlier. Indeed, the four cities have been recognized as "Digital Inclusion Trailblazers" for their digital equity plans and related efforts to fund and implement their strategies (NDIA, 2020). With respect to guidance about process, planners documented that they had gathered stakeholders from government, community organizations, the private sector, and the public. In content, planners demonstrated little deviation from or innovation on guidance about expanding access and opportunities for the public to develop skills to use technology.

\section{Partial characterization of the problem, revelatory prescriptions}

The second research question posed in this study seeks to understand the extent to which digital equity plans may offer novel understandings of digital inequality and strategies to address it. Despite the opportunity to newly define the current problematic circumstances, the plans demonstrate that the notion of individual deficit dominates governments' 
explicit conceptions of digital inequality. Three of four plans add that organizations that could help afflicted individuals face resource deficits themselves. Still, the construal of the problem at the individual and organizational levels is partial. It omits serious consideration of reasons why individuals lack resources or why social service organizations face challenges to financial sustainability. Kansas City's plan perhaps goes the farthest in acknowledging structures of inequality related to the problem by identifying unfavorable local economic conditions and the geospatial nature of deprivation, but it presents few proposals to change these conditions. Even with the partial characterization of the current problematic circumstances, the plans incorporate actions hinting at a deeper understanding of how digital inequality has emerged, in relation to particular actors and institutions. Prescriptions related to ISPs, housing, and the tech industry reveal their relations to digital inequality.

ISPs' role in digital inequality is entirely tacit in the characterization of the problem; however, prescribed actions allude to a relation with the inequitable status quo and how it might change in pursuit of the goal state. The plans of Portland and San Francisco propose that ISPs may be motivated to expand service if given access to governmentowned physical assets and special regulatory consideration. These incentives indicate the trade-offs that municipal governments face to attract investment in Internet infrastructure and to regulate it in the interest of equity (Alizadeh et al., 2017; Stratton et al., 2020). Kansas City's plan calls for a standard agreement for government to use in negotiation with ISPs and other telecommunications providers that "includes some expectation of contribution to Digital Equity" (Kansas City, 2017, p. 20) and for dedication of revenue from 5G infrastructure permits towards digital equity programs. ISPs' profit-seeking motive may dictate why particular communities lack Internet service entirely, or service that is high-quality and affordable, but they are spared scrutiny in plans.

A relationship between housing and digital equity also surfaces in plans' prescribed actions. Residents living in affordable housing developments may lack financial resources to subscribe to Internet service at home, so actions to connect affordable housing make sense intuitively as an effective mechanism for resource distribution. Affordable housing is not just a convenient place to mitigate digital inequality, though. It may directly contribute to the problem through a lack of adequate connection to Internet infrastructure. Seattle's plan targets sufficient connection to high-speed Internet in all multifamily housing through possible revision of building codes, as well as training to sensitize planners and developers to best practices for building connectivity.

The tech industry forms part of the backdrop of digital equity planning, even as the plans avoid foregrounding it. Success in attracting and retaining tech jobs is common to the four cities and representatives from some of the world's largest tech corporations participated in constructing at least two of the plans. Prescriptions to develop a pipeline to high-tech employment, included in the plans of Portland and Seattle, suggest that plan authors value this form of economic participation. Increased access to employment opportunities is among the supposed benefits of resource distribution for digital equity, but the plans do not highlight the distinct desirability of tech jobs. Actions to support STEM education and coding programs for children and adults and placement of underrepresented residents in technology jobs are not explicitly motivated in the plans, yet they reflect the importance and desirability of the tech industry to municipal leaders. Phenomena co-occurring with the growth of the tech industry in cities, such as gentrification and displacement (Chapple, 2017; Stehlin, 2016) and the polarization of high and low wage jobs in the service sector (Autor \& Dorn, 2009; Dwyer \& Wright, 
2019) that condition inequality are not surfaced. The structure of the information economy and its relation to digital inequality are sidestepped in favor of bringing more people into a pipeline to high-tech employment.

Planners certainly face pragmatic constraints in developing digital equity plans. The municipalities in this study have variable financial and organizational resources available within government and specifically dedicated to digital equity. Kansas City, lacking a dedicated organizational unit or budget allocation specifically for digital equity, proposed most of its actions for further planning, along with new funding for digital equity programs. The plans of Portland and Seattle, backed by strong organizational and financial footing within city government and longer institutional trajectories, have relatively similar prescribed actions and reflect coordination with community-based organizations that serve their communities. Despite a large difference in these cities' national shares of tech jobs ( $0.9 \%$ for Portland, $4.3 \%$ for Seattle), their plans both include actions to develop the pipeline to high-tech employment. San Francisco's plan entailed authorship of multiple units in city government and engagement with several of the tech giants based in the Bay Area, as well as significant public consultation. Prescribed actions for an innovation grant to fund community-based organizations, form a pool of sponsors in city government, and form a coalition of organizations working on digital equity, suggest an interest in integrating digital equity across units and boundaries of government.

\section{Recommendations for planners}

For the authors of plans, the social, political, and financial consequences of characterizing digital inequality as anything but a problem of individual deficit may be daunting; however, devoting attention to factors producing individual deficits may permit a more efficient and effective use of limited resources. Two recommendations follow from the analysis of argumentation within plans.

First, the barrier of cost of devices and Internet service recommends direct intervention to increase the financial resources and/or reduce the cost of those items for those people experiencing the problem. Broad, radical interventions might offer residents a universal basic income or increase the local minimum wage. Alternatively, more focused interventions might offer residents ongoing subsidy funds to purchase and maintain private access to devices and residential Internet service. Interventions to reduce the cost of Internet service might generate alternatives to the limitations of commercial ISPs' service, including its footprint, quality, and pricing. Working in cooperation or independently of ISPs, planners might leverage existing fiberoptic networks (including dark fiber) or propose building new networks to offer affordable service to communities not well-served by existing options.

Second, digital inequality's relation to economic development, housing, transportation, and other areas of municipal planning suggests that it might be effectively considered within these other planning processes. For example, some plans indicate that transportation to public access sites is a challenge for residents but reshaping public transportation systems is outside the scope of digital equity planning. Incorporating digital equity as a cross-cutting theme in municipal planning (in addition or as an alternative to digital equity planning) may enable new strategies and coordination to transform structures that manifest as individual deficits. 


\section{Conclusion}

Across plans, novel strategies to mitigate inequality are nascent. Given the national recognition that the cities under study have received for their plans and their successes in building the high-tech economy that is the normative ideal in urban governance (Alizadeh et al., 2017), other cities' development of digital equity plans is likely. This presents an opportunity for the scholarly community to intervene. Scholars of digital inequality can play a crucial role in digital equity planning by translating the lessons of empirical research to planners. In particular, sensitizing planners to digital inequality as a problem related to social, political, and economic structures might inspire novel strategies for its mitigation. Ultimately, the plans' conceptions of digital equity offer an origin to develop alternative interpretations and guidance. 


\section{References}

Accessible, Affordable Internet for All Act, H.R. 7302, $116^{\text {th }}$ Cong. (2020). https://www.congress.gov/bill/116th-congress/house-bill/7302

Alizadeh, T., Grubesic, T. H., \& Helderop, E. (2017). Urban governance and big corporations in the digital economy: An investigation of socio-spatial implications of Google Fiber in Kansas City. Telematics and Informatics, 34(7), 973-986. https://doi.org/10.1016/j.tele.2017.04.007

Beamish, A. (1999). Approaches to community computing: Bringing technology to low-income groups. In D. A. Schön, B. Sanyal \& W. J. Mitchell, (Eds.), High technology in lowincome communities: Prospects for the positive use of information technology (pp. 349368). MIT Press.

Borgstrom, A., Druker, D., \& Sparrow, J. (2005). The technology opportunities program (TOP): Networking our nation - a decade of lessons learned. Community Development, 36(1), 103-119. https://doi.org/10.1080/15575330509489875

Bryson, J. M. (2018). Strategic planning for public and nonprofit organizations: A guide to strengthening and sustaining organizational achievement. John Wiley \& Sons.

Bryson, J. M., Crosby, B. C., \& Bryson, J. K. (2009). Understanding strategic planning and the formulation and implementation of strategic plans as a way of knowing: The contributions of actor-network theory. International Public Management Journal, 12(2), 172-207. https://doi.org/10.1080/10967490902873473

City of Kansas City, Missouri. (2017, March 9). Digital equity strategic plan. https://www.kcmo.gov/home/showdocument?id=3743

Digital Inclusion Network. (2016). Digital equity action plan. City of Portland \& Multnomah County. https://www.portlandoregon.gov/oct/article/643895

City and County of San Francisco. (2019). Digital equity strategic plan 2019-2024. https://sfmohcd.org/sites/default/files/SF_Digital_Equity_Strategic_Plan_2019.pdf

City of Seattle. (2016). Digital equity initiative action plan phase 2: From vision to action. https://www.seattle.gov/Documents/Departments/InformationTechnology/DigitalEquity _PhaseII.pdf

Cooper, T. (2019, July 2). 2019 digital inclusion trailblazers: Leading cities. BroadbandNow. https://broadbandnow.com/report/2019-digital-inclusion-trailblazers/

Digital Equity Act of 2019, H.R. 4486, $116^{\text {th }}$ Cong. (2019). https://www.congress.gov/bill/116thcongress/house-bill/4486

DiMaggio, P., \& Hargittai, E. (2001). From the 'digital divide' to 'digital inequality': Studying Internet use as penetration increases. Working Paper Series (15) Princeton University, Center for Arts and Cultural Policy Studies. https://ideas.repec.org/p/pri/cpanda/workpap15.html.html

DiMaggio, P., Hargittai, E., Celeste, C., \& Shafer, S. (2004). Digital inequality: From unequal access to differentiated use. In K. Neckerman (Ed.), Social inequality (pp. 355-400). Russell Sage Foundation. https://www.russellsage.org/research/reports/dimaggio

Eubanks, V. E. (2007). Trapped in the digital divide: The distributive paradigm in community informatics. The Journal of Community Informatics, 3(2). https://doi.org/10.15353/joci.v3i2.2373 
Eubanks, V. E. (2012). Digital dead end: Fighting for social justice in the information age. MIT Press.

Fairclough, I., \& Fairclough, N. (2012). Political discourse analysis: A method for advanced students. Routledge.

Fairclough, N. (1992). Discourse and text: Linguistic and intertextual analysis within discourse analysis. Discourse \& Society, 3(2), 193-217. https://doi.org/10.1177\%2F0957926592003002004

Fairclough, N., \& Wodak, R. (1997). Critical discourse analysis. In T. A. van Dijk (Ed.), Discourse studies: A multidisciplinary introduction (Vol. 2, pp. 357-378). Sage.

Federal Reserve Bank of Kansas City. (2019). Disconnected: Seven lessons on fixing the digital divide. https://www.kansascityfed.org/community/disconnected

Gangadharan, S. P. (2012). Digital inclusion and data profiling. First Monday, 17(5). https://doi.org/10.5210/fm.v17i5.3821

Gangadharan, S. P. (2017). The downside of digital inclusion: Expectations and experiences of privacy and surveillance among marginal Internet users. New Media \& Society, 19(4), 597-615. https://doi.org/10.1177\%2F1461444815614053

Gonzales, A. (2016). The contemporary US digital divide: From initial access to technology maintenance. Information, Communication \& Society, 19(2), 234-248. https://doi.org/10.1080/1369118X.2015.1050438

Gorski, P. C. (2003). Privilege and repression in the digital era: Rethinking the sociopolitics of the digital divide. Race, Gender \& Class, 10(4), 145-176. https://www.jstor.org/stable/41675106

Gorski, P. C. (2009). Insisting on digital equity: Reframing the dominant discourse on multicultural education and technology. Urban Education, 44(3), 348-364. https://doi.org/10.1177\%2F0042085908318712

Hargittai, E., \& Hinnant, A. (2008). Digital inequality: Differences in young adults' use of the Internet. Communication Research, 35(5), 602-621. https://doi.org/10.1177\%2F0093650208321782

Horrigan, J. B. (2001). The Internet and community networks: Case studies of five US cities. Pew Internet and American Life Project. https://arxiv.org/pdf/cs/0109084.pdf

Horrigan, J. B., \& Wilson, R. H. (2002). Telecommunications technologies and urban development: Strategies in US cities. International Journal of Technology, Policy and Management, 2(3), 338-354. 10.1504/IJTPM.2002.001773

Institute of Museum and Library Services, University of Washington, International City/County Management Association. (2012, January). Building digital communities: A framework for action. IMLS. https://www.imls.gov/publications/building-digital-communitiesframework-action

Kennedy, S. M. (2016) Urban policy mobilities, argumentation and the case of the model city. Urban Geography, 37(1), 96-116. DOI: 10.1080/02723638.2015.1055932

Kvasny, L. (2006). Cultural (re) production of digital inequality in a US community technology initiative. Information, Communication \& Society, 9(2), 160-181. https://doi.org/10.1080/13691180600630740 
Laws, G. (1994). Urban policy and planning as discursive practices. Urban Geography, 15(6), 592-600. https://doi.org/10.2747/0272-3638.15.6.592

Morino, M. (1994, May). Assessment and evolution of community networking. Morino Institute. http://www.morino.org/under_sp_asse.asp

Muro, M. \& Whiton, J. (2018, December 17). Tech is (still) concentrating in the Bay Area: An update on America's winner-take-most phenomenon. Brookings. https://www.brookings.edu/blog/the-avenue/2018/12/17/tech-is-still-concentrating-inthe-bay-area-an-update-on-americas-winner-take-most-economic-phenomenon/

Napoli, P. M., \& Obar, J. A. (2014). The emerging mobile internet underclass: A critique of mobile internet access. The Information Society, 30(5), 323-334. https://doi.org/10.1080/01972243.2014.944726

National Digital Inclusion Alliance. (n.d.). Definitions. https://www.digitalinclusion.org/definitions/

National Digital Inclusion Alliance. (2019). Digital inclusion start-up manual. https://www.startup.digitalinclusion.org

Poister, T. H., \& Streib, G. (2005). Elements of strategic planning and management in municipal government: Status after two decades. Public Administration Review, 65(1), 45-56. https://doi.org/10.1111/j.1540-6210.2005.00429.x

Resta, P. E. (2020). Moving toward digital equity in the technopolis. In C. Zintgraff, S. Suh, B. Kellison, \& P. E. Resta, (Eds.), STEM in the technopolis: The power of STEM education in regional technology policy (pp. 79-89). Springer.

Resta, P. E., \& Laferrière, T. (2008). Issues and challenges related to digital equity. In J. Voogt \& G. Knezek, (Eds.), International handbook of information technology in primary and secondary education (Vol. 20, pp. 765-778). Springer.

Rhinesmith, C. (2016, October 3). Digital equity planning in U.S. cities. Benton Institute for Broadband \& Society. https://www.benton.org/blog/digital-equity-planning-us-cities

Sanyal, B. \& Schön, D. A. (1999). Information technology and urban poverty: The role of public policy. In D. A. Schön, B. Sanyal \& W. J. Mitchell, (Eds.), High technology in lowincome communities: Prospects for the positive use of information technology (pp. 371393). MIT Press.

Schön, D. A. (1999). Introduction. In D. A. Schön, B. Sanyal \& W. J. Mitchell, (Eds.), High technology in low-income communities: Prospects for the positive use of information technology (pp. 1-22). MIT Press.

Servon, L. (2002). Bridging the digital divide: Community, technology and policy. Blackwell.

Servon, L. J., \& Nelson, M. K. (2001). Community technology centers: Narrowing the digital divide in low-income, urban communities. Journal of Urban Affairs, 23(3-4), 279-290. https://doi.org/10.1111/0735-2166.00089

Servon, L. J., \& Nelson, M. K. (2002). The Role of CTCs within the community technology movement. In Servon, L., Bridging the digital divide: Community, technology and policy. Blackwell.

Servon, L. J., \& Pinkett, R. D. (2004). Narrowing the digital divide: the potential and limits of the US community technology movement. In M. Castells (Ed.), The Network Society, (pp. 319-338). Edward Elgar. 
Schools, Health \& Libraries Broadband (SHLB) Coalition. (2016, July). Connecting anchor institutions: A broadband action plan. Benton Foundation. https://www.benton.org/sites/default/files/SHLB\%20Action\%20Plan.pdf

Shipan, C. R., \& Volden, C. (2008). The mechanisms of policy diffusion. American Journal of Political Science, 52(4), 840-857. https://doi.org/10.1111/j.1540-5907.2008.00346.x

Stratton, C., Grubesic, T. H., \& Helderop, E. (2020). Google Fiber Community Connections: Promises, pitfalls, and outcomes in Austin, Texas. Journal of Urban Affairs. https://doi.org/10.1080/07352166.2020.1820872

Strover, S. (2014). The US digital divide: A call for a new philosophy. Critical Studies in Media Communication, 31(2), 114-122. https://doi.org/10.1080/15295036.2014.922207

Strover, S. (2019). Public libraries and 21st century digital equity goals. Communication Research and Practice, 5(2), 188-205. https://doi.org/10.1080/22041451.2019.1601487

Tufekci, Z. (2012). Past and future divides: Social mobility, inequality, and the digital divide in Austin during the tech boom. In J. Straubhaar, J. Spence, Z. Tufekci, \& R. G. Lentz (Eds.), Inequity in the technopolis: Race, class, gender, and the digital divide in Austin (pp. 85-108). University of Texas Press.

Turner, S. M. (2001). Texts and the institutions of municipal government: The power of texts in the public process of land development. Studies in Cultures, Organizations and Societies, 7(2), 297-325. https://doi.org/10.1080/10245280108523562

van Deursen, A. J., \& van Dijk, J. A. (2019). The first-level digital divide shifts from inequalities in physical access to inequalities in material access. New Media \& Society, 21(2), 354375. https://doi.org/10.1177\%2F1461444818797082

van Deursen, A. J., van Dijk, J. A., \& Peter, M. (2015). Increasing inequalities in what we do online: A longitudinal cross sectional analysis of Internet activities among the Dutch population (2010 to 2013) over gender, age, education, and income. Telematics and Informatics, 32(2), 259-272. https://doi.org/10.1016/j.tele.2014.09.003

van Dijk, T. A. (1997). Discourse as interaction in society. In T. A. van Dijk (Ed.), Discourse as social interaction (Vol. 2, pp. 1-37). Sage.

van Dijk, T. A. (1993). Principles of critical discourse analysis. Discourse \& Society, 4(2), 249283. https://doi.org/10.1177\%2F0957926593004002006

Wiig, A. (2016). The empty rhetoric of the smart city: from digital inclusion to economic promotion in Philadelphia. Urban Geography, 37(4), 535-553. https://doi.org/10.1080/02723638.2015.1065686

Wodak, R., \& Meyer, M. (2015). Critical discourse studies: History, agenda, theory and methodology. In R. Wodak \& M. Meyer (Eds.), Methods of critical discourse studies (pp. 1-22). Sage.

Wynne, M. E., \& Cooper, L. F. (2007). Power up: The campaign for digital inclusion. Microsoft Corporation, Office of Economic Development and Innovation, U.S. Public Sector. http://www.digitalaccess.org/pdf/White_Paper.pdf

Zillien, N., \& Hargittai, E. (2009). Digital distinction: Status-specific types of internet usage. Social Science Quarterly,90(2), 274-291. https://doi.org/10.1111/j.15406237.2009.00617.x 


\section{Annex 1: Plan documents' structures and authorship}

\begin{tabular}{|c|c|c|c|c|}
\hline & Kansas City & Portland & San Francisco & Seattle \\
\hline Length & $\begin{array}{l}26 \text { pages }+51 \\
\text { pages appendices }\end{array}$ & $\begin{array}{l}17 \text { pages }+7 \\
\text { pages appendices }\end{array}$ & $\begin{array}{l}31 \text { pages }+9 \\
\text { pages appendices }\end{array}$ & 44 pages \\
\hline $\begin{array}{l}\text { Authors (as } \\
\text { indicated in } \\
\text { document) }\end{array}$ & $\begin{array}{l}\text { Mayor's Policy } \\
\text { Director, Assistant } \\
\text { City Manager, } \\
\text { external consultant }\end{array}$ & $\begin{array}{l}\text { Digital Inclusion } \\
\text { Network }\end{array}$ & $\begin{array}{l}\text { Committee on } \\
\text { Information } \\
\text { Technology, } \\
\text { Mayor's Office } \\
\text { of Housing \& } \\
\text { Community } \\
\text { Development, } \\
\text { Office of the City } \\
\text { Administrator }\end{array}$ & $\begin{array}{l}\text { City of Seattle } \\
\text { Digital Equity } \\
\text { Initiative (Mayor, } \\
\text { Department of } \\
\text { Information } \\
\text { Technology, } \\
\text { Office of Civil } \\
\text { Rights) }\end{array}$ \\
\hline \multicolumn{5}{|c|}{ Major sections of document } \\
\hline $\begin{array}{l}\text { Letter from } \\
\text { mayor }\end{array}$ & $\mathrm{X}$ & & $\mathrm{X}$ & $\mathrm{X}$ \\
\hline $\begin{array}{l}\text { Background on } \\
\text { the problem } \\
\text { (general) }\end{array}$ & $\mathrm{X}$ & & & \\
\hline $\begin{array}{l}\text { Background on } \\
\text { the problem } \\
\text { (local) }\end{array}$ & $\mathrm{X}$ & $\mathrm{X}$ & $\mathrm{X}$ & $\mathrm{X}$ \\
\hline Definitions & $\mathrm{X}$ & & & $\mathrm{X}$ \\
\hline $\begin{array}{l}\text { Description of } \\
\text { related past } \\
\text { efforts }\end{array}$ & $\mathrm{X}$ & & & $\mathrm{X}$ \\
\hline $\begin{array}{l}\text { Description of } \\
\text { planning } \\
\text { process }\end{array}$ & & $\mathrm{X}$ & $\mathrm{X}$ & $\mathrm{X}$ \\
\hline $\begin{array}{l}\text { Named goals or } \\
\text { priorities used } \\
\text { to organize } \\
\text { prescribed } \\
\text { actions }\end{array}$ & 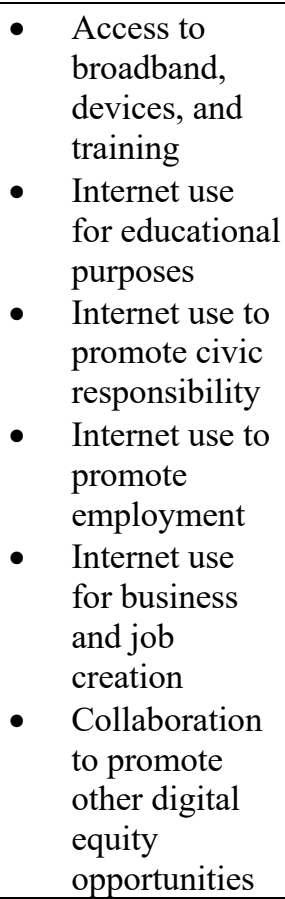 & $\begin{array}{ll}\text { - } & \text { Access } \\
\text { - } & \text { Support and } \\
\text { training } \\
\text { - } & \text { Leadership } \\
\text { and capacity } \\
\text { building } \\
\text { - Connecting to } \\
\text { the digital } \\
\text { economy } \\
\text { Policy }\end{array}$ & $\begin{array}{ll}\text { - } & \text { Access } \\
\text { - } & \text { Digital skills } \\
& \text { and usage } \\
\text { - } & \text { Long-term } \\
& \text { Impact }\end{array}$ & $\begin{array}{ll}\text { - } & \text { Devices and } \\
\text { technical } \\
\text { - } & \text { Conport } \\
\text { - } & \text { Skills training }\end{array}$ \\
\hline
\end{tabular}




\section{Annex 2: Categorization of actions prescribed in plans}

\begin{tabular}{|c|c|c|c|c|}
\hline & Kansas City & Portland & San Francisco & Seattle \\
\hline $\begin{array}{l}\text { Expand Internet } \\
\text { access (reduce } \\
\text { cost of } \\
\text { residential } \\
\text { service and/or } \\
\text { expand public } \\
\text { access) }\end{array}$ & & $\begin{array}{l}\text { (1.1) Extend free } \\
\text { Wi-Fi into low- } \\
\text { income } \\
\text { neighborhoods } \\
\text { (1.2) Encourage } \\
\text { providers to } \\
\text { expand low-cost } \\
\text { Internet service } \\
\text { through incentives }\end{array}$ & $\begin{array}{l}\text { (Goal 1) } \\
\text { Connect } \\
\text { affordable } \\
\text { housing to city } \\
\text { network, new } \\
\text { housing to have } \\
\text { multiple } \\
\text { provider options } \\
\text { (Goal 1) Expand } \\
\text { low-cost Internet } \\
\text { options among } \\
\text { Internet service } \\
\text { providers (ISPs) } \\
\text { through } \\
\text { incentives }\end{array}$ & $\begin{array}{l}\text { (C2.1) Expand } \\
\text { hotspot lending } \\
\text { to underserved } \\
\text { individuals } \\
\text { (C3.3) Public } \\
\text { Wi-Fi for } \\
\text { disadvantaged } \\
\text { and underserved } \\
\text { areas } \\
\text { (C3.4) Wi-Fi in } \\
\text { building at } \\
\text { community } \\
\text { centers }\end{array}$ \\
\hline $\begin{array}{l}\text { Expand access } \\
\text { to computing } \\
\text { devices (reduce } \\
\text { cost of devices } \\
\text { for personal } \\
\text { ownership } \\
\text { and/or expand } \\
\text { public access) }\end{array}$ & & $\begin{array}{l}\text { (1.4) Expand } \\
\text { sources of } \\
\text { recycled devices } \\
\text { to provide to } \\
\text { residents }\end{array}$ & $\begin{array}{l}\text { (Goal 1) } \\
\text { Establish } \\
\text { pipeline for } \\
\text { device recycling }\end{array}$ & $\begin{array}{l}\text { (D1.1) Plan to } \\
\text { expand access to } \\
\text { assistive tech for } \\
\text { public access } \\
\text { (D2.1) Promote } \\
\text { device recycling } \\
\text { program for low- } \\
\text { income residents } \\
\text { (D2.2) Subsidize } \\
\text { device purchase } \\
\text { for low-income } \\
\text { residents }\end{array}$ \\
\hline Provide training & & $\begin{array}{l}\text { (2.3) Expand } \\
\text { culturally-specific } \\
\text { training curricula }\end{array}$ & & $\begin{array}{l}\text { (S1.1) Train } \\
\text { families with } \\
\text { students in three } \\
\text { Title I schools } \\
\text { (S1.4) Train } \\
\text { small businesses } \\
\text { owned by } \\
\text { minorities and } \\
\text { women }\end{array}$ \\
\hline $\begin{array}{l}\text { Compile } \\
\text { information } \\
\text { about and } \\
\text { promote } \\
\text { community use } \\
\text { of options for } \\
\text { access and } \\
\text { training }\end{array}$ & & $\begin{array}{l}\text { (1.3) Create an } \\
\text { inventory of } \\
\text { broadband service } \\
\text { options for public } \\
\text { (2.1) Create an } \\
\text { inventory of } \\
\text { training programs }\end{array}$ & $\begin{array}{l}\text { (Goal 1) Raise } \\
\text { awareness of } \\
\text { low-cost Internet } \\
\text { options }\end{array}$ & $\begin{array}{l}\text { (D3.1) Promote } \\
\text { local programs } \\
\text { with low-cost } \\
\text { devices, public } \\
\text { access, training } \\
\text { (D3.2) Expand } \\
\text { awareness of } \\
\text { tech support } \\
\text { options } \\
\text { (S1.3) Increase } \\
\text { awareness of } \\
\text { training for } \\
\text { vulnerable } \\
\text { workers, } \\
\text { employers, } \\
\text { service providers }\end{array}$ \\
\hline
\end{tabular}




\begin{tabular}{|c|c|c|c|c|}
\hline & Kansas City & Portland & San Francisco & Seattle \\
\hline & & & & $\begin{array}{l}\text { (S3.1) Market } \\
\text { training and tech } \\
\text { support options }\end{array}$ \\
\hline $\begin{array}{l}\text { Compile } \\
\text { information for } \\
\text { operational use } \\
\text { (i.e., within } \\
\text { government and } \\
\text { community- } \\
\text { based } \\
\text { organizations) }\end{array}$ & $\begin{array}{l}\text { (14) Identify } \\
\text { existing local } \\
\text { government } \\
\text { programs that } \\
\text { support digital } \\
\text { equity } \\
\text { (17) Review } \\
\text { Google Fiber- } \\
\text { sponsored public } \\
\text { access utilization } \\
\text { annually }\end{array}$ & $\begin{array}{l}\text { (2.2) Gather data } \\
\text { about connectivity } \\
\text { in affordable } \\
\text { housing }\end{array}$ & $\begin{array}{l}\text { (Goal 3) Gather } \\
\text { data about } \\
\text { digital divide } \\
\text { problem every 2- } \\
3 \text { years, tabulate } \\
\text { in scorecard and } \\
\text { accountability } \\
\text { report }\end{array}$ & \\
\hline $\begin{array}{l}\text { Develop pipeline } \\
\text { to high-tech } \\
\text { employment }\end{array}$ & & $\begin{array}{l}\text { (4.1) Support } \\
\text { programs to } \\
\text { prepare and place } \\
\text { underrepresented } \\
\text { people in jobs in } \\
\text { the "technology } \\
\text { economy" } \\
\text { (4.2) Support } \\
\text { STEAM programs } \\
\text { for K-12 students }\end{array}$ & & $\begin{array}{l}\text { (S1.2) Support } \\
\text { STEM and } \\
\text { coding training } \\
\text { for out-of-school } \\
\text { students and } \\
\text { adults }\end{array}$ \\
\hline $\begin{array}{l}\text { Develop } \\
\text { community- } \\
\text { based } \\
\text { organizations' } \\
\text { capacity to } \\
\text { serve } \\
\text { community }\end{array}$ & $\begin{array}{l}\text { (19) Dedicate } \\
\text { funding from } \\
\text { small cell } \\
\text { permits to } \\
\text { support } \\
\text { organizations' } \\
\text { projects } \\
\text { (20) Provide } \\
\text { annual funding } \\
\text { to organizations } \\
\text { with primary } \\
\text { digital equity } \\
\text { mission }\end{array}$ & $\begin{array}{l}\text { (3.1) Strengthen } \\
\text { network } \\
\text { (3.2) Create an } \\
\text { annual summit } \\
\text { (3.3) Expand } \\
\text { funding sources }\end{array}$ & $\begin{array}{l}\text { (Goal 1) } \\
\text { Strengthen } \\
\text { public access } \\
\text { "safety net" with } \\
\text { updated } \\
\text { technology, new } \\
\text { sites } \\
\text { (Goal 2) } \\
\text { Innovation } \\
\text { funding grant to } \\
\text { organizations } \\
\text { (Goal 3) Form } \\
\text { coalition of } \\
\text { organizations } \\
\text { working on } \\
\text { digital equity } \\
\text { (Goal 3) Train } \\
\text { organizations }\end{array}$ & $\begin{array}{l}\text { (C3.1) Develop } \\
\text { sustainability } \\
\text { strategy for } \\
\text { public access } \\
\text { points } \\
\text { (S2.1) Increase } \\
\text { organizations' } \\
\text { training capacity } \\
\text { (S3.2) Form } \\
\text { funding } \\
\text { collaborative to } \\
\text { coordinate } \\
\text { resources }\end{array}$ \\
\hline $\begin{array}{l}\text { Develop plans } \\
\text { and/or policies } \\
\text { within } \\
\text { government }\end{array}$ & $\begin{array}{l}\text { (1) Roadmap to } \\
\text { advance access } \\
\text { (Internet, } \\
\text { devices, } \\
\text { training) } \\
\text { (3) Roadmap for } \\
\text { education (PPP } \\
\text { with devices for } \\
\text { K-12 students, } \\
\text { training) } \\
\text { (5) Roadmap for } \\
\text { civic } \\
\text { responsibility }\end{array}$ & $\begin{array}{l}\text { (5.1) Develop } \\
\text { strategy for } \\
\text { funding digital } \\
\text { equity in } \\
\text { affordable } \\
\text { housing } \\
\text { (5.2) Engage } \\
\text { leaders to take } \\
\text { action } \\
\text { (5.3), Develop } \\
\text { digital equity lens } \\
\text { for policy }\end{array}$ & $\begin{array}{l}\text { (Goal 2) Form a } \\
\text { pool of sponsors } \\
\text { in city } \\
\text { government }\end{array}$ & $\begin{array}{l}\text { (C1.1) Design } \\
\text { best practices to } \\
\text { incorporate } \\
\text { broadband in } \\
\text { building plans } \\
\text { (C1.2) Evaluate } \\
\text { apartment } \\
\text { building codes } \\
\text { for Internet } \\
\text { infrastructure, } \\
\text { propose changes }\end{array}$ \\
\hline
\end{tabular}




\begin{tabular}{|c|c|c|c|c|}
\hline & Kansas City & Portland & San Francisco & Seattle \\
\hline & $\begin{array}{l}\text { (7) Roadmap for } \\
\text { employment } \\
\text { (9) Roadmap for } \\
\text { business and job } \\
\text { creation } \\
\text { (11) Roadmap } \\
\text { for collaboration } \\
\text { (13) Enact } \\
\text { resolution to } \\
\text { support local } \\
\text { efforts against } \\
\text { digital divide } \\
\text { (15) Add digital } \\
\text { equity to rubric } \\
\text { to project } \\
\text { evaluation } \\
\text { (16) Add digital } \\
\text { equity to } \\
\text { housing and } \\
\text { neighborhood } \\
\text { plans } \\
\text { (18,21) Develop } \\
\text { funding plan and } \\
\text { pursue funding }\end{array}$ & & & \\
\hline Other & $\begin{array}{l}\text { (2) Access } \\
\text { project } \\
\text { (4) Education } \\
\text { project } \\
\text { (6) Civic } \\
\text { responsibility } \\
\text { project } \\
\text { (8) Employment } \\
\text { project } \\
\text { (10) Business } \\
\text { and job creation } \\
\text { project } \\
\text { (12) } \\
\text { Collaboration } \\
\text { project }\end{array}$ & $\begin{array}{l}(1.5,1.6) \text { Digital } \\
\text { equity pilot } \\
\text { projects for } \\
\text { affordable } \\
\text { housing and } \\
\text { people } \\
\text { experiencing } \\
\text { homelessness }\end{array}$ & $\begin{array}{l}\text { (Goal 2) } \\
\text { Innovation } \\
\text { challenges to } \\
\text { help residents } \\
\text { overcome } \\
\text { known } \\
\text { challenges }\end{array}$ & $\begin{array}{l}\text { (D3.2) Expand } \\
\text { access to tech } \\
\text { support } \\
\text { (C3.2) Set up } \\
\text { charging stations } \\
\text { at public access } \\
\text { points }\end{array}$ \\
\hline
\end{tabular}

